\title{
Production responses from lambs grazed on Lolium perenne selected for an elevated water-soluble carbohydrate concentration
}

\author{
Michael R.F. LEE ${ }^{a *}$, Evan L. JonES ${ }^{\mathrm{a}}$, Jonathan M. MoORBYa, \\ Mervyn O. HumPHREYs ${ }^{\mathrm{a}}$, Michael K. TheOdOROU ${ }^{\mathrm{a}}$, \\ John C. MACRAE ${ }^{\mathrm{b}}$, Nigel D. SCOLlaN ${ }^{\mathrm{a}}$ \\ a Institute of Grassland and Environmental Research, Plas Gogerddan, \\ Aberystwyth, SY23 3EB, UK \\ ${ }^{\mathrm{b}}$ Rowett Research Institute, Greenburn Road, Bucksburn, Aberdeen, AB21 9SB, UK
}

(Received 21 June 2001; accepted 8 November 2001)

\begin{abstract}
Liveweight gain was assessed in lambs grazing perennial ryegrass (Lolium perenne) bred for an elevated water-soluble carbohydrate (WSC) concentration (experimental var. Ba11353) compared to an intermediate WSC control (var. AberElan). Both grass varieties had similar heading dates and overall forage yield characteristics. The two grasses were sown separately in each of three replicate sward plots $(0.137$ ha each) laid out in a randomised block design. A core group of five Welsh Mountain ewes and their singleton lambs (Bluefaced Leicester, sire), initial liveweights of 50 and $14 \mathrm{~kg}$ (s.e. 0.6 and 0.3 ), respectively, were continuously stocked on these plots over three consecutive $21 \mathrm{~d}$ experimental periods. Swards were maintained at a target surface height of 6-7 cm with the use of sward adjustment animals. Core sheep were weighed every three weeks and adjustment animals whenever they were added to or removed from the plots. Lamb liveweight gain $\left(\mathrm{g} \cdot \mathrm{d}^{-1}\right)$ was calculated from the core group of lambs. Lamb production (kg liveweight.ha ${ }^{-1}$ over each $21 \mathrm{~d}$ period) was calculated from the liveweight change of all the lambs. Water-soluble carbohydrate concentrations were higher $(P=0.03)$ and neutral detergent fibre concentrations (NDF) were lower $(P=0.01)$ in the high WSC grass (HWSC) compared to the control. In vitro dry matter digestibilities (DMD) were higher for HWSC $(P<0.01)$. Lamb liveweight gain $(P=0.03)$ and production $(P=0.06)$ were greater on HWSC compared with the control by approximately 12 and $23 \%$, respectively. The increased lamb production resulted from the combined effect of higher liveweight gains and carrying capacity on HWSC. Correlation matrices indicated strong relationships between liveweight gain and grass WSC concentration $(r=0.67 ; P<0.05)$ and fibre concentration $(r=-0.73 ; P<0.05)$. The results show that grazing forages selected for elevated concentrations of WSC and reduced fibre, compared to a control increases the liveweight gain of suckling lambs.
\end{abstract}

water-soluble carbohydrate / grazing / lambs / Lolium perenne / liveweight gain

* Correspondence and reprints

Tel.: 44 (0)1970 823084; fax: 44 (0)1970 828357; e-mail: michael.lee @ bbsrc.ac.uk 
Résumé - Performances de production d'agneaux pâturant du ray-grass anglais (Lolium perenne) sélectionné pour sa concentration en glucides hydrosolubles élevée. Le gain de poids vif a été évalué chez des agneaux pâturant du ray-grass anglais (Lolium perenne) sélectionné pour sa concentration en glucides hydrosolubles (WSC) élevée (variété expérimentale Ba11353) et comparé à un témoin avec une concentration intermédiaire en WSC (variété AberElan). Les deux variétés de ray-grass ont eu des dates d'épiaison et un rendement fourrager globalement comparables. Elles ont été semées séparément sur des parcelles d'une surface de 0,137 ha chacune avec 3 répétitions selon un dispositif expérimental aléatoire par blocs. Un groupe fixe de cinq brebis de race Welsh Mountain et leur agneau unique (bélier Bluefaced Leicester), de poids vifs initiaux de 50 et $14 \mathrm{~kg}$ (e.s. : 0,6 et 0,3 ) respectivement, a été continuellement présent sur les parcelles pendant trois périodes expérimentales consécutives de 21 jours. Le tapis végétal a été maintenu à une hauteur seuil de 6-7 cm en utilisant des animaux supplémentaires pour ajuster le couvert prairial. Les ovins expérimentaux du groupe fixe ont été pesés toutes les trois semaines et les animaux destinés à l'ajustement chaque fois qu'ils ont été ajoutés ou enlevés des parcelles. Le gain de poids vif des agneaux $\left(\mathrm{g} \cdot \mathrm{j}^{-1}\right)$ a été calculé à partir du groupe fixe. La production des agneaux à l'hectare $(\mathrm{kg}$ de poids vif $\cdot \mathrm{ha}^{-1}$ au cours de chaque période de 21 jours) a été calculée en tenant compte du changement de poids vif de tous les agneaux. La concentration en glucides hydrosolubles a été supérieure $(P=0,03)$ et celle en NDF moindre $(P=0,01)$ pour la variété riche en WSC (HWSC) comparativement au témoin. La digestibilité in vitro de la matière sèche (DMD) a augmenté avec $\operatorname{HWSC}(P<0,01)$. Le gain de poids vif des agneaux $(P=0,03)$ et leur production $(P=0,06)$ ont été respectivement plus élevés d'environ 12 et $23 \%$ avec HWSC comparativement au témoin. La production accrue des agneaux résulte de l'effet combiné des gains de poids vif et d'un chargement plus importants sur HWSC. Les matrices de corrélation ont indiqué des rapports forts entre le gain de poids vif, la concentration en WSC du fourrage $(r=0,67 ; P<0,05)$ et la concentration en fibres $(r=-0,73 ; P<0,05)$. Les résultats montrent que le pâturage de fourrages sélectionnés pour leur concentration élevée en WSC et faible en fibres, comparativement à un témoin, augmente le gain de poids vif des agneaux de lait.

glucide hydrosoluble / pâturage / agneaux / Lolium perenne / gain de poids vif

\section{INTRODUCTION}

Water-soluble carbohydrates (WSC) contained in fresh forages are the most readily available source of energy for the grazing ruminant, and as such, low concentrations of WSC in herbage can decrease the efficiency of protein utilisation, limit productivity and contribute to poor utilisation of dietary protein [7]. It has been suggested that efficient microbial protein synthesis relies upon the synchronous provision of energy and protein nitrogen to the rumen microbial population [22]. In ruminant diets, characterised by an insufficient supply of readily available energy for balanced rumen fermentation to occur, acetate production dominates with a resultant reduction in the efficiency of utilisation of both nitrogen and energy [3].
Grass breeding has resulted in the development of forage grasses with increased concentrations of WSC (20-40\% of DM) compared to conventional commercial varieties $(10-15 \%$ of DM) $[9,10,20,23]$. In initial lamb production experiments liveweight gain $\left(\mathrm{g} \cdot \mathrm{d}^{-1}\right)$ was consistently higher from a high WSC Lolium perenne variety (Aurora) in comparison to a control variety (S23); $29.2,12.4$ and $10.3 \%$ over three consecutive years [5]. In addition, Jones and Sant [12] reported that sheep showed a strong grazing preference for high WSC when offered a choice between low and high WSC grasses. Jones and Roberts [11] suggested that this increased grazing preference was due to a higher 'palatability' of the grass with elevated sugar and reduced fibre concentrations. Siever-Kelly et al. [21] noted 
that this preference was related more to the soluble carbohydrate concentration of a plant than to digestibility, and only when the soluble carbohydrate concentrations were similar there was a preference for the more digestible material. Siever-Kelly et al. [21] used glyphosate to spray topped-pastures and delay the loss of cell contents, thereby increasing grass WSC concentration and digestibility. They observed that lambs offered a choice between the glyphosate sprayed pastures and controls, preferentially grazed the former, resulting in higher liveweight gains and wool growth [15].

The objective of this study was to extend the observations of the above authors [5, $11,12,15,21]$ by assessing the productivity of lambs offered a perennial ryegrass bred for high WSC compared to an intermediate WSC control. Thereby determining if using grass varieties bred for enhanced WSC concentration, i.e. quality traits, may have relevance to practical agriculture by enhancing efficiency and reducing the cost of sheep production.

\section{MATERIALS AND METHODS}

\subsection{Experimental site, design and allocation to treatment}

Two Lolium perenne swards with similar heading dates, Ba11353, a high water soluble carbohydrate (WSC) variety (HWSC), and AberElan, an intermediate WSC variety (control), were sown in plots ( 0.137 ha each) laid out in a split-block design and replicated three times in July 1997 at the Institute of Grassland and Environmental Research, Aberystwyth, Plas Gogerddan site $\left(52^{\circ} 25^{\prime} \mathrm{N}\right.$, $\left.4^{\circ} 05^{\prime} \mathrm{W}\right)$. These swards were maintained by grazing with sheep. A core group of five Welsh ewes and their one month old singleton lambs (Bluefaced Leicester $\sigma^{\top}$ ), initial liveweights 50.2 (s.e. 0.60) $\mathrm{kg}$ and 13.7 $(0.32) \mathrm{kg}$, respectively, were put on each of the plots in a stratified random manner, according to ewe and lamb liveweight.
Animals were continuously grazed on these plots over three consecutive $21 \mathrm{~d}$ experimental periods (I, II and III) starting on 6th May 1998.

\subsection{Sward management and measurements}

Swards were cut to a surface height ( $\mathrm{SSH}$ ) of $3 \mathrm{~cm}$, one month prior to the start of the experiment, to obtain uniform regrowth. Fertiliser was applied after cutting to give an application of $250 \mathrm{~kg} \cdot \mathrm{ha}^{-1}$ of 25.5.5 (N, P and K; Norsk hydro, Sluiskil, The Netherlands). Sward surface height was measured every week in a "w" transect using a Hill Farm Research Organisation sward stick, and sward adjustment animals (ewes and singletons of the same breed as core animals) were used to maintain the height of the sward at approximately 6-7 cm. If the SSH was greater than the upper limit of the defined range $(7 \mathrm{~cm})$ then a ewe and lamb were added to the plot, if the SSH had fallen back below the lower limit of the defined range $(6 \mathrm{~cm})$ then the additional animals were removed. The addition and removal of animals was done on a weekly basis.

Herbage intake was calculated over each $21 \mathrm{~d}$ period using the differential growth method as assessed by exclosure cages [6]. Three exclosure cages were allocated at random in each plot. Intake was estimated by comparing herbage growth inside and outside the cage. Herbage shears (Makita $100 \mathrm{~mm}$ UM103D Makita Corporation, Anjo, Japan) were used to cut four $0.1 \times 1 \mathrm{~m}$ parallel strips of grass to ground level outside the cage along each edge of the cage, and two inside the cage. The cages were then relocated at random. The herbage was dried at $80{ }^{\circ} \mathrm{C}$ for $24 \mathrm{~h}$ and the intake calculated per ewe and lamb according to the following formula:

$\operatorname{DMI}\left(\mathrm{kg} \mathrm{DM} \cdot \mathrm{d}^{-1}\right)=\frac{\left(\left[\mathrm{H}_{\mathrm{i}}-\left(\mathrm{H}_{0} / 2\right)\right] \times 5 \times 10^{4}\right) \times \mathrm{A}}{\mathrm{D}} / \mathrm{EU}$

where $\mathrm{H}_{\mathrm{i}}=$ dried herbage mass inside the cage in $\mathrm{kg} ; \mathrm{H}_{\mathrm{O}}=$ dried herbage mass outside 
the cage in $\mathrm{kg} ; \mathrm{A}=$ area of plot (0.137 ha); $\mathrm{D}=$ number of grazing days; $\mathrm{DMI}=$ dried herbage intake per experimental unit (ewe and singleton); EU = number of experimental units.

Ewe and lamb intakes were calculated for each exclosure cage and a mean was calculated for each paddock.

Herbage yield was measured every $21 \mathrm{~d}$ by cutting a $1 \times 0.3 \mathrm{~m}$ strip at $3 \mathrm{~cm}$ above ground level (using a hedge trimmer, Husqvarna, Sweden) under the three exclosure cages in each plot, before relocation of the cages. These samples were then oven dried (at $80{ }^{\circ} \mathrm{C}$ for $24 \mathrm{~h}$ ) and weighed. Herbage yields were then calculated as $\mathrm{kg} \mathrm{DM} \cdot \mathrm{ha}^{-1} \cdot \mathrm{d}^{-1}$ by simple area conversion.

For WSC analysis grass samples were cut at $3 \mathrm{~cm}$ above ground level with herbage shears at $10.00 \mathrm{~h}$ at weekly intervals from five random locations in each paddock. Every three weeks, to coincide with the end of each period, a more comprehensive chemical analysis was conducted for concentrations of WSC, acid detergent fibre (ADF), neutral detergent fibre (NDF), in vitro dry matter digestibility (DMD) and total nitrogen (TN). All grass samples were collected in an icebox containing crushed ice and then frozen $\left(-20^{\circ} \mathrm{C}\right)$ prior to analysis.

\subsection{Animal measurements}

All sheep were weighed every three weeks, on two consecutive days, at the same time of day, and sward adjustment animals were also weighed whenever they were added to or removed from the plots, after the sward surface height measurements. Individual lamb performance (liveweight gain; $\mathrm{g} \cdot \mathrm{d}^{-1}$ ) was calculated using data from the core group of lambs and lamb production per hectare obtained from the live weight changes of all the lambs. After weighing the animals were returned to the plots for the commencement of the next period.

\subsection{Chemical and statistical analysis}

Water-soluble carbohydrate (WSC) was extracted in water and determined spectrophotometrically using anthrone in sulphuric acid on a Technicon Autoanalyser attached to a peak height analyser [25]. Organic matter (OM) was calculated from total DM minus ash, analysed by combustion at $550{ }^{\circ} \mathrm{C}$ for $6 \mathrm{~h}$ in a muffle furnace. Total nitrogen was determined by microKjeldahl technique using 'Kjeltec equipment' (Perstorp Analytical Ltd., Maidenhead, Berkshire). Neutral detergent fibre was determined as described by Van Soest et al. [27] and acid detergent fibre was analysed according to Van Soest and Wine [28] using the Tecator Fibretec System equipment (Tecator Ltd., Thornbury, Bristol). In vitro dry matter digestibility (DMD) was determined following the method of Jones and Hayward [13].

All measurements were analysed using split-plot analysis of variance [14] to compare HWSC vs. control and variety $\times$ period interaction. The block effect was not significant and was subsequently pooled with the error. Variety main effect was tested against the pooled main plot error and variety $\times$ period effects tested in the sub-plot. Correlation relationships between the main measurements were also established.

\section{RESULTS}

\subsection{Sward characteristics and herbage quality}

The SSH averaged $6.5 \mathrm{~cm}$ (s.e. 0.30) across the experimental periods for both varieties. Herbage yield was approximately $5.8 \%$ higher from HWSC plots compared to the control plots during the measurement period (Tab. I).

The concentrations of WSC were higher in HWSC $(P<0.05)$ and they fluctuated across experimental periods $(P=0.03)$. During periods I and II the differential between 
Table I. Chemical composition of the two grass varieties HWSC and control during the three experimental grazing periods.

\begin{tabular}{|c|c|c|c|c|c|c|c|c|c|c|}
\hline & \multicolumn{2}{|c|}{ Period I } & \multicolumn{2}{|c|}{ Period II } & \multicolumn{2}{|c|}{ Period III } & \multirow[b]{2}{*}{ s.e.d. } & \multicolumn{3}{|c|}{ * Significance } \\
\hline & Control & HWSC & Control & HWSC & Control & HWSC & & V & $\mathrm{P}$ & $\mathrm{V} \times \mathrm{P}$ \\
\hline \multicolumn{11}{|c|}{ Chemical composition $\left(\mathrm{g} \cdot \mathrm{kg}^{-1} \mathrm{DM}\right)$} \\
\hline WSC & 89 & 143 & 75 & 113 & 84 & 92 & 6.7 & 0.03 & 0.03 & 0.08 \\
\hline $\mathrm{ADF}$ & 255 & 222 & 279 & 250 & 274 & 267 & 14.0 & 0.002 & 0.06 & NS \\
\hline $\mathrm{NDF}$ & 487 & 411 & 540 & 473 & 514 & 506 & 24.9 & 0.01 & 0.02 & NS \\
\hline $\mathrm{CP}$ & 169 & 149 & 166 & 200 & 194 & 181 & 12.7 & NS & NS & NS \\
\hline $\operatorname{DMD}(\%)$ & 64.7 & 70.1 & 65.6 & 70.6 & 60.8 & 62.1 & 2.32 & 0.007 & 0.015 & NS \\
\hline \multicolumn{11}{|l|}{$\left(\mathrm{kg} \mathrm{DM} \cdot \mathrm{ha}^{-1} \cdot \mathrm{d}^{-1}\right)$} \\
\hline Herbage yield & 75 & 103 & 85 & 91 & 68 & 47 & 4.0 & 0.1 & 0.001 & NS \\
\hline
\end{tabular}

$\mathrm{WSC}=$ water soluble carbohydrate; $\mathrm{ADF}=$ acid detergent fibre $\mathrm{NDF}=$ neutral detergent fibre $\mathrm{DMD}=$ in vitro dry matter digestibility; $\mathrm{CP}=$ crude protein; ${ }^{*} \mathrm{~V}, \mathrm{P}$ and $\mathrm{V} \times \mathrm{P}$ represent the effects of variety, period and variety $\times$ period interaction.

Table II. Animal productivity of the core lambs grazing HWSC and the control grass varieties during the three experimental periods.

\begin{tabular}{|c|c|c|c|c|c|c|c|c|c|c|}
\hline & \multicolumn{2}{|c|}{ Period I } & \multicolumn{2}{|c|}{ Period II } & \multicolumn{2}{|c|}{ Period III } & \multirow[b]{2}{*}{ s.e.d. } & \multicolumn{3}{|c|}{ * Significance } \\
\hline & Control & HWSC & Control & HWSC & Control & HWSC & & V & $P$ & $\mathrm{~V} \times \mathrm{P}$ \\
\hline Intake & 1.16 & 0.97 & 1.32 & 1.69 & 1.16 & 1.09 & 0.24 & NS & 0.06 & NS \\
\hline Gain & 271 & 312 & 194 & 244 & 175 & 186 & 16.3 & 0.03 & 0.001 & 0.08 \\
\hline Production & 193 & 256 & 131 & 177 & 114 & 107 & 18.4 & 0.06 & 0.001 & 0.04 \\
\hline Capacity & 34.1 & 46.2 & 34.1 & 36.5 & 29.2 & 29.2 & 3.44 & 0.1 & 0.004 & 0.06 \\
\hline
\end{tabular}

Gain $=$ liveweight gain, $\mathrm{g} \cdot \mathrm{d}^{-1} ;$ production $=\mathrm{kg}$ liveweight $\cdot \mathrm{ha}^{-1} \cdot \mathrm{period}^{-1} ;$ capacity $=$ carrying capacity, ewes $\cdot \mathrm{ha}^{-1}$; intake $=\mathrm{kg}$ DM. $\mathrm{d}^{-1} . * \mathrm{~V}, \mathrm{P}$ and $\mathrm{V} \times \mathrm{P}$ represent the effects of variety, period and variety $\times$ period interaction.

HWSC and the control was 54 and $38 \mathrm{~g} \cdot \mathrm{kg}^{-1}$ $\mathrm{DM}$, respectively, but in period III it was only $8 \mathrm{~g} \cdot \mathrm{kg}^{-1} \mathrm{DM}$ (Tab. I). In vitro DMD of HWSC was higher (67.6 vs. $63.7 \%$ ), while the fibre fraction concentrations were higher on the control $(P<0.01)$. Both DMD and NDF concentration varied significantly across periods $(P=0.02$ and $P=0.015$, respectively). Crude protein concentration was not significantly different between the varieties.

\subsection{Animal performance}

The combined estimated DM intakes of the ewes and lambs, calculated by the exclosure cage method were not significantly different between the two varieties, although there was a tendency for intake to vary between periods (Tab. II, $P=0.06$ ). Liveweight gains $\left(\mathrm{g} \cdot \mathrm{d}^{-1}\right)$ of animals grazing HWSC were higher than control animals $(P<0.05)$ and varied significantly with 
period $(P=0.001)$. The correlation coefficients indicated a positive relationship between liveweight gain and the WSC concentration of the herbage, and a negative relationship between fibre concentration and liveweight gain $(r=0.67$ and -0.73 ; $P<0.05$, respectively).

Animal production ( $\mathrm{kg}$ liveweight $\cdot \mathrm{ha}^{-1}$ ) was higher $(23 \% ; P=0.06)$ from animals on HWSC plots compared to the control animals. The higher level of production from HWSC was positively related to WSC concentration and carrying capacity $(r=0.66$ and $0.87 ; P<0.05$, respectively) and negatively related to fibre concentration $(r=-0.76 ; P<0.05)$. Significant period effects were found for liveweight gain, animal production and carrying capacity. There were also significant interaction effects (variety $\times$ period) for animal production and an interaction trend for both liveweight gain and carrying capacity $(P=0.08$ and $P=0.06$, respectively).

\section{DISCUSSION}

\subsection{Chemical composition and herbage intake}

The difference in WSC concentration between the control and HWSC of $33 \mathrm{~g} \cdot \mathrm{kg}^{-1}$ DM (representing a 20-40\% increase) observed was similar to that reported by Humphreys [10]. Whereas Humphreys [9, 10] reported consistent differences between varieties throughout the year, in the present study they were not sustained across all three $21 \mathrm{~d}$ experimental periods. This may reflect the fact that the work of Humphreys $[9,10]$ was based upon small plots and individual plants grown in controlled conditions as opposed to measurements from large scale plots subjected to meteorological and pathogenic stresses used in the current study, which are known to cause fluctuations in the chemical composition of the grasses [19]. The differences in DMD between the two varieties were most likely related to the differences in fibre and WSC concentration. The higher fibre concentration of the lower WSC grass was expected because higher WSC grasses tend to have proportionately less structural carbohydrate to account for the elevated WSC fraction of the plant [20]. The reduction in crude protein concentration reported by Humphreys [9] in grasses of high WSC concentration was not observed here, in accordance with the findings of Smith et al. [23].

Daily herbage yield was greater for HWSC compared to the control in periods I and II. This was reflected in the greater carrying capacity of the HWSC sward during these periods, which subsequently declined in period III. The mean daily herbage production $\left(78.2 \mathrm{~kg} \mathrm{DM} \cdot \mathrm{ha}^{-1} \cdot \mathrm{d}^{-1}\right)$ across all three periods was higher than with a similar comparison of Lolium perenne varieties during May-June of $54.5 \mathrm{~kg} \mathrm{DM} \cdot \mathrm{ha}^{-1} \cdot \mathrm{d}^{-1}$ [6], which may be explained by the higher rate of fertiliser application used in this study, 250 vs. $200 \mathrm{~kg} \mathrm{~N} \cdot \mathrm{ha}^{-1}$.

It has been reported that exclosure cages can introduce errors when used to determine herbage yield on areas that are open to continuous grazing $[6,18]$. These errors are often the result of topographical differences in the plot and uneven sward growth as a result of urine patches, which contribute to produce a net increase in herbage production, or weed patches, which result in a reduction in herbage production. Care was taken in this study to reduce some of these errors by random rotation of the cages and by taking four strips outside the cage instead of the usual two [4]. However, the intake data collected were approximately $18 \%$ lower than the AFRC [1] estimated intake for a ewe suckling a singleton lamb of $80 \mathrm{~g} \mathrm{DM} \cdot \mathrm{kg}^{-1} \mathrm{~W}^{0.75}$. Also, by the end of the experiment, the lambs were between 25 and $30 \mathrm{~kg}$ liveweight and would have been consuming approximately $1.0 \mathrm{~kg} \mathrm{DM} \cdot \mathrm{d}^{-1}$ [2]. Despite the potential limitations of the procedure, the data obtained does provide an estimate of the relative differences between 
HWSC and the control paddocks in terms of intake and yield, although an alternative approach e.g. n-alkanes [16] should be considered in future.

\subsection{Animal performance}

The liveweight gain of the suckling lambs (247 and $213 \mathrm{~g} \cdot \mathrm{d}^{-1}$ for animals on HWSC and control grasses, respectively) are similar to those reported by Evans and Scurlock [8] on high WSC (var. Aurora) and control (var. Melle) varieties of perennial ryegrass (237 and $223 \mathrm{~g} \cdot \mathrm{d}^{-1}$, respectively). Although Aurora produced significant production responses, this grass was not popular in commerce because of its poor resistance to forage diseases (e.g. crown rust; Puccinia coronata). Grass breeding has alleviated this problem and is not an issue with HWSC (Ba11353). The overriding relationship, which arose from the animal performance results was the association between liveweight gain and WSC concentration of the herbage $(r=0.67 ; P<0.05$; Tab. II). In periods I and II there were significant differences in liveweight gain between HWSC and the control, which correlated with the significant differences in WSC concentration. In contrast in period III the difference in WSC concentrations between varieties was minimal and liveweight gains were similar. However, the liveweight gain response was also negatively correlated with fibre concentration. Thornton and Minson [26] suggested that voluntary intake of forages by ruminants was largely dependent on retention time in the rumen, which was principally affected by the fibre components of the diet. This may suggest that the lower fibre concentration of the HWSC grass may have resulted in the increase in liveweight gain through a greater intake. However, as the intake data is not conclusive it is difficult to further postulate any link between fibre concentration and liveweight gain.

The increased animal performance (lamb liveweight gain; $\mathrm{g} \cdot \mathrm{d}^{-1}$ ) contributed to greater
$(P=0.06)$ animal production (kg liveweight $\mathrm{ha}^{-1}$ ) on HWSC compared to the control. Animal production was correlated with the WSC concentration of the herbage $(r=0.66$; $P<0.05)$. Period effects similar to that for liveweight gain and WSC concentration were observed. These were probably the result of meteorological differences between the periods, which have been shown to dramatically alter the chemical composition of forages [19]. The animal production response was a multiplicative effect between the greater liveweight gain and the greater carrying capacity, which is related in turn to the greater daily herbage production, of the HWSC paddocks. The interaction effects between period and variety in animal production and liveweight gain may imply that HWSC grass is not advantageous under certain conditions, such as with a low herbage yield, over the control.

The increased liveweight gain of lambs grazing on HWSC compared with the control (in periods I and II) may be related to improvements in the balance of energy and nitrogen supply to the rumen through the elevated level of WSC, as this is the most rapidly available source of energy to the micro-organisms [7]. This may enhance microbial protein synthesis, change microbial fermentation resulting in a reduction in ammonia and methane production and an improved glucogenic:lipogenic volatile fatty acid ratio [24]. Carruthers and Neil [4] supplemented Friesian cows on high or low nitrogen pasture diet with non-structural carbohydrate and in both cases observed significant reductions in rumen ammonia concentrations. Formulation of diets that improve the balance in nitrogen and energy release into the rumen on an hourly basis increased the efficiency of microbial protein synthesis [22] and the growth rate of lambs [30]. In ewes fed an asynchronous diet the levels of plasma urea were increased, suggesting a reduction in nitrogen efficiency [29]. A dairy cow experiment [17], offered the same grass varieties used in this study, observed a significant increase in milk yield 
on the high WSC grass, further suggesting a link between improved animal performance and WSC and/or fibre concentration of the fed herbage. Whether the increased performance in this study was entirely due to the elevated WSC concentration of the grass, or the reduced concentration of fibre or a combination of the two, remains unclear.

\section{CONCLUSION}

Increases in liveweight were achieved when the differential in grass WSC concentration was approximately $40-50 \mathrm{~g} \cdot \mathrm{kg}^{-1} \mathrm{DM}$, but not when the chemical compositions of the experimental grasses were similar. The factors that control these fluctuations in chemical composition are not yet fully understood, but it will be important to identify how to sustain the WSC differential to ensure consistency of response when feeding high WSC grasses. This study endorses the hypothesis that feeding ruminants on forages that are bred for quality traits (as well as for yield and persistency) may contribute to enhance efficiency and reduce the cost of sheep production.

\section{ACKNOWLEDGEMENTS}

The authors would like to thank the farm staff at IGER Plas Gogerddan for the care of the animals and experimental plots, and Susan Youell for her help in analysing the many samples collected. This work was funded by a LINK Sustainable Livestock Production programme involving the Ministry of Agricultural Fisheries and Food, Milk Development Council, Meat and Livestock Commission and Germinal Holdings Ltd.

\section{REFERENCES}

[1] AFRC, Technical committee on responses to nutrients, Reports No. 5, Nutritive requirements of ruminant animals: Energy, Nutritional Abstracts and Reviews, Series B, 60, CAB International, Wallingford, Oxon, 1990.
[2] AFRC, Technical committee on responses to nutrients, Energy and protein requirements of ruminants, CAB International, Wallingford, Oxon, 1995.

[3] Beever D.E., Rumen function, in: Forbes J.M. France J. (Eds.), Quantitative aspects of ruminant digestion and metabolism, CAB International, Wallingford, Oxon, 1993.

[4] Carruthers V.R., Neil P.G., Milk production and ruminal metabolites from cows offered two pasture diets supplemented with non-structura carbohydrate, N.Z. J. Agric. Res. 40 (1997) 513-521.

[5] Davies D.A., Fothergill M., Jones D., Assessment of contrasting PRG, with and without white clover, under continuous sheep stocking in the uplands. 1. Animal production from the grass varieties, Grass Forage Sci. 44 (1989) 431-439.

[6] Davies D.A., Fothergill M., Jones D., Assessment of contrasting PRG, with and without white clover, under continuous sheep stocking in the uplands. 3. Herbage production, quality and intake, Grass Forage Sci. 46 (1991) 39-49.

[7] Dove H., Milne J.A., Digesta flow and rumen microbial protein production in ewes grazing perennial ryegrass, Aust. J. Agric. Res. 45 (1994) 1229-1245.

[8] Evans W.B., Scurlock R.V., Herbage and lamb production of Aberystwyth Aurora, British Grassland Society, Occasional Symposium Efficient Sheep production from grass 21 (1986) 193-194.

[9] Humphreys M.O., Water-soluble carbohydrates in PRG breeding. 1. Genetic differences among cultivars and hybrid progeny grown as spaced plants, Grass Forage Sci. 44 (1989) 231-236.

[10] Humphreys M.O., Water-soluble carbohydrates in PRG breeding. II. Cultivar and hybrid progeny performance in cut plots, Grass Forage Sci. 44 (1989) 237-244.

[11] Jones E.L., Roberts J.E., A note on the relationship between palatability and WSC content in PRG, Ir. J. Agric. Res. 30 (1991) 163-167.

[12] Jones E.L., Sant F.I., A photographic technique for assessing grazing behaviour and foraging activities of sheep on swards of selected PRG of varying WSC content, Third Research Conference of Greenmount College of Agriculture and Horticulture, Antrim, UK, 1992, pp. 73-74.

[13] Jones D.I.H., Hayward M.V., The effect of pepsin treatment of herbage on the prediction of dry matter digestibility from solubility in fungal cellulase solutions, J. Sci. Food Agric. 26 (1975) 711-718.

[14] Lawes Agricultural Trust, Genstat 5, Rothamstead Experimental Station, Harpendon, Hertfordshire, UK, 1995.

[15] Leury B.J., Siever-Kelly C., Gatford K.L., Simpson R.J., Dove H., Spray-topping annual grass pasture with glyphosate to delay loss of 
feeding value during summer. IV. Diet composition, herbage intake, and performance in grazing sheep, Aust. J. Agric. Res. 50 (1999) 487-495.

[16] Mayes R.W., Wright I.A., Lamb C.S., McBean A., The use of long-chain n-alkanes as markers for estimating intake and digestibility of herbage in cattle, Anim. Prod. 42 (1986) 457-467.

[17] Miller L.A., Theodorou M.K., MacRae J.C., Evans R.T., Adesogan A.T., Humphreys M.O., Scollan N.D., Moorby J.M., Milk production and $\mathrm{N}$ partitioning in dairy cows offered perennial ryegrass selected for high water-soluble carbohydrate concentrations, South Afr. J. Anim Sci. 29 (1999) 281-282.

[18] Parsons A.J., Collett B., Lewis J., Changes in the structure and physiology of a perennial ryegrass sward when released from a continuous stocking managements implications for use of exclusion cages continuously stocked swards, Grass Forage Sci. 39 (1984) 1-9.

[19] Pollock C.J., Jones T., Seasonal patterns of fructan metabolism in forage grasses, New Phytol. 83 (1979) 9-15.

[20] Radojevic I., Simpson R.J., St John J.A., Humphreys M.O., Chemical composition and in vitro digestibility of lines of Lolium perenne selected for high concentrations of WSC, Aust. J. Agric. Sci. 86 (1994) 443-452.

[21] Siever-Kelly C., Leury B.J., Gatford K.L., Simpson R.J., Dove H., Spray-topping annual grass pasture with glyphosate to delay loss of feeding value during summer. II. Herbage intake, digestibility, and diet selection in penned sheep, Aust. J. Agric. Res. 50 (1999) 465-474.

[22] Sinclair L.A., Garnsworthy P.C., Newbold J., Buttery P.J., Effects of synchronising the rate of dietary energy and nitrogen release in diets with similar carbohydrate composition on rumen fermentation and microbial protein synthesis in sheep, J. Agric. Sci. 124 (1995) 463-472.
[23] Smith K.F., Simpson R.J., Oram R.N., Lowe K.F., Kelly K.B., Evans P.M., Humphreys M.O., Seasonal variation in the herbage yield and nutritive value of perennial ryegrass (Lolium perenne) cultivars with high or normal herbage watersoluble carbohydrate concentrations grown in three contrasting Australian dairy environments, Aust. J. Exp. Agric. 38 (1998) 821-830.

[24] Sutoh M., Obara Y., Miyamoto S., The effect of sucrose supplementation on kinetics of nitrogen, ruminal propionate and plasma glucose in sheep, J. Agric. Sci. 126 (1996) 99-105.

[25] Thomas T.A., An automated procedure for the determination of soluble carbohydrates in herbage, J. Sci. Food Agric. 28 (1977) 639-642.

[26] Thornton R.F., Minson D.J., The relationship between voluntary intake and mean apparent retention time in the rumen, Aust. J. Agric. Res. 23 (1972) 871-877.

[27] Van Soest P.J., Collaborative study on acid detergent fibre and lignin, J. Assoc. Offic. Anal. Chem. 56 (1973) 781-784.

[28] Van Soest P.J., Wine R.H., Use of detergents in the analysis of fibrous feeds. IV. Determination of plant and cell wall constituents, J. Assoc. Offic. Anal. Chem. 50 (1967) 50-55.

[29] Witt M.W., Sinclair L.A., Wilkinson R.G., Buttery P.J., The effects of synchronising the rate of dietary energy and nitrogen supply to the rumen on milk production and metabolism of ewes offered grass silage based diets, Anim. Sci. 71 (2000) 187-195.

[30] Witt M.W., Sinclair L.A., Wilkinson R.G., Buttery P.J., The effects of synchronising the rate of dietary energy and nitrogen supply to the rumen on the metabolism and growth of ram lambs given food at a restricted level, Anim. Sci. 69 (1999) 627-636. 